Article

\title{
Application of Individual Digestate Forms for the Improvement of Hemp Production
}

\author{
Jiř́i Velechovský $\mathbb{D}^{\mathbb{D}}$, Matěj Malík (D), Lukáš Kaplan and Pavel Tlustoš *
}

check for updates

Citation: Velechovský, J.; Malík, M.; Kaplan, L.; Tlustoš, P. Application of Individual Digestate Forms for the Improvement of Hemp Production. Agriculture 2021, 11, 1137. https:// doi.org/10.3390/agriculture11111137

Academic Editor: Claudio Marzadori

Received: 8 October 2021

Accepted: 11 November 2021

Published: 13 November 2021

Publisher's Note: MDPI stays neutral with regard to jurisdictional claims in published maps and institutional affiliations.

Copyright: (c) 2021 by the authors. Licensee MDPI, Basel, Switzerland. This article is an open access article distributed under the terms and conditions of the Creative Commons Attribution (CC BY) license (https:// creativecommons.org/licenses/by/ $4.0 /)$.
Department of Agroenvironmental Chemistry and Plant Nutrition, Czech University of Life Sciences Prague, Kamýcká 129, 16500 Prague, Czech Republic; velechovsky@af.czu.cz (J.V.); malikmatej@af.czu.cz (M.M.); kaplanl@af.czu.cz (L.K.)

* Correspondence: tlustos@af.czu.cz

\begin{abstract}
In a two-year vegetation field experiment, the fertilizing effects of by-products from the agricultural biogas plant-a solid phase of digestate (SPD) and a liquid phase of digestate (LPD) were studied and compared with mineral fertilization (NPK) on the biomass yield, content and nutrient uptake by Cannabis sativa L. plants. Furthermore, the agrochemical properties of the soil were evaluated at the end of the experiment. In all variants of the experiment, a uniform nitrogen dose of $150 \mathrm{~kg} / \mathrm{ha}$ was applied. The dose of other nutrients corresponded to the fertilizer used. The biggest fertilizing effect, and therefore the greatest hemp biomass yield and nutrient uptake, was demonstrated when combining SPD and LPD fertilization in one treatment. However, the differences were statically insignificant $(p \leq 0.05)$. The applied amount appeared to be sufficient for the nutrition of hemp plants and was comparable to mineral fertilization. The distribution of nutrients between leaves and stems varied depending on the nutrient monitored. Analyses after the end of the experiment did not show different contents of accessible nutrients in the soil on the studied variants. The content of accessible risk elements in the soil was not affected by the application of the SPD and the LPD. The experiment showed that cannabis plants are able to achieve equivalent biomass yields ( $8.68 \mathrm{t} / \mathrm{ha}$ ) using the combination of LPD and SPD by-products from a biogas plan compared to commercial mineral fertilizer $(7.43 \mathrm{t} / \mathrm{ha})$. Therefore, we can recommend a split application of LPD and SPD as a suitable alternative to mineral fertilization. Due to prolonged nutrient release from SPD, we can expect a smaller negative environmental impact than current fertilization practices.
\end{abstract}

Keywords: Cannabis sativa L.; fertilization; biogas plants; solid phase of digestate; liquid phase of digestate

\section{Introduction}

As a result of ever-increasing greenhouse gas emissions from burning fossil fuels, there has been a great boom in the development and use of biogas in recent years, especially as a source of environmentally friendly energy in the production of heat and electricity [1-3]. It is estimated that the consumption of biogas in Europe in the coming years will double, from 14.5 gigawatts in 2012 to 29.5 gigawatts in 2022 [4]. From the perspective of farmers, agricultural biogas plants also offer the possibility of stable extra income [5].

Biogas is produced by the anaerobic microbiological degradation of organic compounds, and it usually contains two major components: methane and carbon dioxide; it can also include other gases such as hydrogen sulfide and nitrogen $\left(\mathrm{N}_{2}\right)$ [6]. The positive aspect of anaerobic digestion is the fact that it reduces pathogens, kills viruses, fungi, bacteria of the genus Listeria, Salmonella and Escherichia coli and inactivates plant seeds [7-11]. The secondary product of this wet fermentation is digestate [12]. Hemp appears to be a suitable alternative crop for biogas production due to high biomass yields. It also has low adverse environmental impacts compared to other crops commonly used in Europe for biogas production (corn, sugar and beet) [13-15]. Considering soil ecology and sustainable soil use 
in the Czech Republic, Cannabis sativa L. could work as a plant that alternates commonly grown plants used for biogas production. The aim is to reach a closed feedstock circle in which Cannabis sativa L. is grown due to using biogas station outputs as a fertilizer. In addition, soil conditions are improved by Cannabis sativa L. growth, and the consequently gained biomass might be used for further biogas production.

\subsection{Composition of Digestate}

Digestate is a heterogeneous liquid formed as a by-product of biogas production from organic matter with a significant proportion of undecomposed solid organic fraction $(60-80 \%$ in dry matter). The dry matter of digestate is in the range of $7-12 \%$ and is comparable to slurry. It has a similar nitrogen content in fresh matter as manure $(0.2-1 \%)$ but a higher $\mathrm{pH}$ value ranging from 7-8 [16-18]. The nutrient content in the dry mass (DM) of digestate is reported by Möller and Müller as follows: total N: $3.1-14 \%$, P: $0.6-1.7 \%$ and K: $1.9-4.3 \%$ [19]. The application of digestate as an organic fertilizer to agricultural land is already considered as a standard method of its use [20,21]. The use of biogas residue as a substitute for mineral fertilizers has also been mentioned by other authors. Studies show that the use of digestate from agricultural biogas plants reduces the environmental risks that are generally associated with the use of mineral fertilizers and, at the same time, achieves comparable yield parameters for agricultural crops such as Medicago sativa L. and Triticum aestivum $\mathrm{L}$. At the same time, the availability of nutrients depends on the input of raw materials, and it is not possible to say that, in general, we achieve better field crop yields by using by-products of anaerobic digestion [19,22-24].

The solid phase (SPD) and the liquid phase of digestate (LPD) are formed by the mechanical separation of the digestate in order to obtain two homogeneous materials. The composition of the SPD and the content of macronutrients and micronutrients is influenced by the composition of the input raw materials into the fermentation process and the retention time of the raw materials in the fermenter [25,26]. Slurry, silage corn, grass silage, cereals, sorghum and sugar beet pulp are produced as input materials [27]. The dry matter content in the SPD is in the range of 21-30\% [16]. Möller and Müller present a content of nitrogen in the range of $2.2-3 \%$, a content of phosphorus of $1.9 \%$ and a potassium content of $3.6 \%$ in the dry matter (DM) of the solid part of the digestate [19]. Due to the chemical composition and physical features, the applied SPD can positively affect biomass yield and soil structure [28,29].

Kolár et al. [26] refer to the LPD as a dilute solution containing a wide range of nutrients in a form acceptable to plants. The values given for the liquid part of the digestate (DM) are $7.7-9.2 \%$ for nitrogen, $0.4-0.7 \%$ for phosphorus and $3.9 \%$ for potassium [19]. The LPD appears to be a suitable raw material for application to arable land during vegetation, and its fertilizing and irrigation effects can be used [16,26]. Schievano et al. [30] characterize the LPD as an organic fertilizer that contains mineral nutrients along with organic matter. The dry matter of the LPD is in the range of $0.8-4 \%$. Nitrogen is mainly present in mineral form, which means that it is easily accessible to plants. Its concentration is in the range of $0.15-0.30 \%$, which is comparable to the potassium content. A study presented by Coelho et al. showed concentrations of plant essential nutrients as follows: $\mathrm{N}(6.6-24.1 \%$, average $11.7 \%), \mathrm{P}(0.81-3.28 \% \mathrm{DW}$, average $1.74 \%)$ and $\mathrm{K}(0.81-17.35 \% \mathrm{DW}$, average $6.15 \%)$. Because the proportions of $\mathrm{N}-\mathrm{P}-\mathrm{K}$ are variable in each digestate, it is necessary to provide an analysis of the specific digestates before actual application on the field [31]. Other nutrients are present in significantly lower concentrations [32].

\subsection{Hemp (Cannabis sativa L.) Plants}

Hemp (Cannabis sativa L.) comes from western Asia and is one of the earliest domesticated agricultural crops. According to Chinese historical records and archaeological findings, its cultivation for fiber and seeds dates back to the period of approximately 3000 4000 years BCE $[33,34]$. Over the centuries, hemp fibers have been used to manufacture 
fabrics, sails, ropes and paper, while hemp seeds have been used as protein-rich food and feed [35].

According to European regulations, industrial hemp may contain no more than $0.3 \%$ of tetrahydrocannabinol (THC). In several European countries (e.g., the Netherlands and Belgium), a maximum THC content of $0.2 \%$ is allowed. In the European Union, only hemp cultivars approved by the European Commission-i.e., industrial hemp cultivars with a THC content below $0.2 \%$-are permitted for industrial hemp cultivation [36-38].

Hemp biomass has been used for energy purposes for centuries. However, the energetic use of hemp has traditionally been limited to the use of oil pressed from hemp seeds; e.g., for lighting purposes. To date, the commercial use of industrial hemp biomass for energy purposes has been proposed in many countries. Hemp can be used to produce heat and energy by directly burning biomass from whole plants, or it can be converted to biomass-bound energy into liquid or gaseous transport biofuels such as bioethanol and biogas [39-41].

According to van der Werf et al. [42], the maximum yield of industrial hemp stems in field cultivation can be reached at a plant density of 90 plants $/ \mathrm{m}^{2}$. Amaducci et al. [43] reached an average yield of 14 tons/ha in a three-year field hemp cultivation experiment. The fertilization of hemp plants with nitrogen at a rate of $150 \mathrm{~kg} \mathrm{~N} /$ ha ensures optimal plant height, higher seed yield, higher stem strength [44] and overall high biomass production [44-47]. Nitrogen uptake is, according to Landi [48], greatest in the early stages of growth. An adequate nitrogen supply is ensured if the nitrogen content of the plant in dry matter is in the range of 5-6\% [49]. The need for nitrogen by plants depends on the variety, as stated by Finnan and Burke [46]. Alaru et al. [50] compared the use of nitrogen by plants in variants where ammonium nitrate, waste sludge and beef manure were applied. The nitrogen dose for all variants was chosen identically, at $100 \mathrm{~kg} \mathrm{~N} / \mathrm{ha}$. Their results showed the suitability of using sludge as an organic fertilizer in the cultivation of cannabis for energy purposes. On the contrary, the application of beef manure failed to ensure the maximum yield of biomass. Malceva et al. [51] demonstrated the negative effects of increasing the nitrogen dose on the fiber content of the hemp stem. During a growing season with a higher level of precipitation, an application of $60 \mathrm{~kg} \mathrm{~N} /$ ha is recommended. According to the authors, this dose can be considered optimal. Regarding nitrogen cannabis nutrition, application rates vary from country to country. In Canada, a rate of $60-90 \mathrm{~kg} \mathrm{~N} / \mathrm{ha}$ is used, while in EU countries, higher rates are used, ranging from $80-160 \mathrm{~kg} / \mathrm{ha}$ and depending on soil properties and climatic conditions.

Phosphorus from the soil is taken up evenly by the plant, and its consumption is increased during the flowering and ripening period of the seeds [44]. Phosphorus uptake by cannabis plants ranges from $25-38 \mathrm{~kg} / \mathrm{ha}$, depending on the yield [45]. Ivanyi [49] states that a sufficient supply of phosphorus is at a content of $0.5-0.6 \% \mathrm{P}$ in young fully developed leaves. The required amount of phosphorus to form one ton of dry plant matter is $1.7 \mathrm{~kg}$. If the soil is rich in phosphorus, fertilization with this nutrient can be omitted [52].

Potassium is an important nutrient for the formation of cannabis stems and fibers. Interactions between nitrogen and phosphorus increase the quality of the fiber and the yield of hemp stalks. Potassium is mostly absorbed by cannabis plants during periods of intensive growth [48]. According to Barron et al. [47], potassium requirements for cannabis plants are high. They range from 75 to $100 \mathrm{~K} \mathrm{~kg} / \mathrm{ha}$, and in extreme cases up to $300 \mathrm{~kg} / \mathrm{ha}$. However, hemp is able to use potassium from the deeper layers of the soil profile. Cannabis concentrates most of the potassium in the stem, at up to 70-75\% [46]. Iványi and Izsáki [53] state that the optimal potassium content in the plant is $2.7-3.0 \%$.

According to Johnson [44] and Landi [48], calcium is also necessary for soils with a neutral $\mathrm{pH}$ due to its high consumption in the growth of the root system, stems and seeds. Landi [48] states that the need for calcium, together with nitrogen and potassium, is dominant for cannabis in terms of macronutrients. Depending on the yield, calcium intake is in the range of $151-227 \mathrm{~kg} / \mathrm{ha}$ at yields of $8-10$ tons $/ \mathrm{ha}$. In soils with a deficiency, 
compensatory fertilization is necessary. Cannabis plants absorb calcium mainly at the end of the growing season.

Magnesium is involved in ensuring the good health of the plant [44]. Landi [48] indicates a magnesium uptake by cannabis plants in the range of $36-54 \mathrm{~kg} / \mathrm{ha}$, depending on the yield.

From micronutrients, hemp initially accumulates zinc and copper into the vegetative organs of the plant; later, it transports them to the generative organs, while iron, boron and manganese accumulate mainly in the vegetative organs.

For the field study of hemp growth, we hypothesized that the application of byproducts from a biogas station can sufficiently saturate plants with nutrients to achieve a comparable yield to hemp fertilized by mineral NPK fertilizers. The goal of our experiment was to verify our formulated hypotheses.

\section{Materials and Methods}

\subsection{Vegetation Experiment Establishment}

Cannabis plants were grown in a precise two-year vegetation field experiment. The experiment occurred on a demonstration and experimental site of the Faculty of Agrobiology, Food and Natural Resources of the Czech University of Life Sciences in Prague (GPS $50^{\circ} 7^{\prime} 40^{\prime \prime} \mathrm{N}$ and $14^{\circ} 22^{\prime} 33^{\prime \prime} \mathrm{E}$ ). The land is located at an altitude of $286 \mathrm{~m}$ above sea level, with an average annual temperature of $9.1^{\circ} \mathrm{C}$ and an average total annual precipitation of $495 \mathrm{~mm}$ [54]. The soil type is a partly degraded Chernozem—slightly agglomerated on loess and loess clays.

\subsection{Description of the Used Hemp Variety}

Cannabis sativa L. variety "Tiborszállásí", native to Hungary, was used in a precise field experiment. It is a dioecious variety with a proportion of sex individuals in the stand of approximately 1:1. In the case of cultivation, in order to achieve the maximum biomass yield, the growing season is in the range of 105-110 days; in our case, the plants were harvested after 101 days for both years of the experiment. This variety is specific for its early ripening and provides a high yield of stems as well as green biomass. The THC content is declared to be below $0.2 \%$ [36].

\subsection{Origin of the Digestate and Its Separation into Liquid and Solid Parts}

Within the experiment, a digestate originated from the agricultural biogas station Krásná Hora nad Vltavou with an energy output of $526 \mathrm{kWh}$. Corn silage, grass silage and livestock manure from local stables were used as energy sources. On average, over 20 tons of silage and 44 tons of cattle manure served as daily input. The solid and liquid phases were obtained by the mechanical separation of the digestate on the principle of a centrifuge and a press. All used raw materials were taken in the required amount before starting the experiment directly from the mentioned biogas plant. Some of the raw materials, which were applied only during the experiment, were stored in closed containers in a cooling box at a constant temperature of $4{ }^{\circ} \mathrm{C}$.

\subsection{Layout of Individual Plots and Sowing of Plants}

The area in which the experiment took place was divided into 12 separate sub-plots measuring $2.5 \mathrm{~m} \times 5 \mathrm{~m}$. Eighty-five grams of seed were sown on each plot, up to $12.5 \mathrm{~cm}$ distance per row at a depth of $3 \mathrm{~cm}$. Thus, a total of $1050 \mathrm{~g}$ of seed was sown for the entire area of the experiment. The seed rate was calculated from the seeding amount value (70 kg seed/ha).

In the experiment, four variants were established. Each variant was realized in three repetitions arranged such that two identical fertilization variants were not adjacent. 


\subsection{Amount of Applied Fertilizers in Individual Variants}

In the first (NPK) variant, a mineral fertilizer was used in which nitrogen, phosphorus and potassium were added to the soil. Nitrogen was supplied in the form of ammonium nitrate with limestone containing $27 \%$ nitrogen $\left(50 \% \mathrm{NH}_{4}{ }^{+}, 50 \% \mathrm{NO}_{3}{ }^{-}\right)$. The amount of nitrogen determined for the field experiment was $150 \mathrm{~kg} / \mathrm{ha}$. The dose was chosen depending on the intention to use the cannabis (biomass yield), according to the authors Sausserde and Adamovičs [55], Vera, Malhi, Phelps, May and Johnson [45] and Finnan and Burke [46]. Phosphorus was supplied at a rate of $20 \mathrm{~kg} / \mathrm{ha}$ in the form of triple superphosphate with a phosphorus content of $21 \%\left(48 \% \mathrm{P}_{2} \mathrm{O}_{5}\right)$. Potassium was supplied at a rate of $150 \mathrm{~kg} / \mathrm{ha}$ in the form of a potassium salt $\left(60 \% \mathrm{~K}_{2} \mathrm{O}\right)$.

The second variant included a corresponding dose of the SPD converted to a nitrogen content corresponding to $150 \mathrm{~kg} \mathrm{~N} / \mathrm{ha}$, with respect to the first control variant. The analysis of the SPD itself revealed a dry matter of $21.71 \%$ and a nitrogen content of $2.49 \%$ in the dry matter. For the delivery of $150 \mathrm{~kg} \mathrm{~N} / \mathrm{ha}$, it was necessary to deliver $34.80 \mathrm{~kg}$ of SPD on a partial plot with an area of $12.5 \mathrm{~m}^{2}$. The application of the SPD took place 14 days before sowing, with simultaneous incorporation to a depth of about $8 \mathrm{~cm}$.

The third variant was fertilized with a divided dose of SPD and LPD in a ratio of $\mathrm{N}(1: 1)$, such that the total dose corresponded to $150 \mathrm{~kg} \mathrm{~N} / \mathrm{ha}$. A corresponding dose of $17.4 \mathrm{~kg} / 12.5 \mathrm{~m}^{2}$ was separated into the soil two weeks before sowing. The LPD fertilization took place three times during the vegetation, at two-week intervals, with the first application taking place 32 days after sowing. Later application was impossible in practice due to the involvement of cannabis. The LPD at $6 \%$ dry mass contained $5.78 \% \mathrm{~N}$ in dry matter. For the purposes of the experiment, it was necessary to supply $27.01 \mathrm{~kg}$ of the LPD divided into three equal batches, weighing $9 \mathrm{~kg}$ per sub-plot. For each of the three applications, the LPD was applied using a can.

The fourth variant was fertilized only with the LPD, divided into four doses. In the fourth variant, it was necessary to supply a quantity of $54 \mathrm{~kg}$ of the LPD per sub-plot. The application was identical to the previous variant. The amount of nitrogen supplied in individual variants during the vegetation is shown in Table 1.

Table 1. The amount of nitrogen supplied in individual variants during vegetation.

\begin{tabular}{cccccc}
\hline \multicolumn{5}{c}{ The Amount of N Supplied (kg/ha) } \\
\hline \multirow{2}{*}{ Variant } & Basic Fertilization & $\begin{array}{c}\mathbf{1 .} \\
\text { Additional Fertilization }\end{array}$ & $\begin{array}{c}\text { Additional Fertilization } \\
\text { Additional Fertilization }\end{array}$ & Total \\
\hline NPK & 150 & 0 & 0 & 0 & 150 \\
SPD & 150 & 0 & 0 & 0 & 150 \\
SPD + LPD & 75 & 25 & 25 & 25 & 150 \\
LPD & 75 & 25 & 25 & 25 \\
\hline
\end{tabular}

LPD fertilization in the third and fourth variants was performed using a watering can 3 times in an interval of 14 days during the phase of intensive cannabis growth. Prior to the actual application, a groove was formed, into which the LPD was applied and then covered with soil to prevent volatilization of the ammonium. The purpose of this method of application was to simulate a hose applicator commonly used in agricultural practice. During the vegetation, the plants were not treated against diseases or pests. The inter-row treatment against weeds was performed using a hand hoe as needed. The amount of individual biogas by-product for the delivery of $150 \mathrm{~kg} \mathrm{~N} / \mathrm{ha}$ was as follows: SPD-27.8 t/ha, LPD—43.2 t/ha, combined dose of SPD + LPD—13.9 + 21.6 t/ha, respectively.

\subsection{Harvesting and Plants Sampling, Soil Sampling}

Cannabis plants were harvested by hand by plucking, including the root, from an area of $1 \mathrm{~m}^{2}$, separately from each plot of all variants. After washing and drying the roots, the whole biomass from $1 \mathrm{~m}^{2}$ was weighed, and the yield was subsequently evaluated. 
Individual plant parts (root, stem and leaf) were separated from the harvested plant sample. These samples for analysis were then dried and homogenized. After the plants were harvested, soil samples were taken from individual plots. Samples were taken with a soil probe (20 punctures) to a soil profile depth of $20 \mathrm{~cm}$. The samples were used to determine agrochemical properties. Analyses of all samples took place at the Department of Agroenvironmental Chemistry and Plant Nutrition, Czech University of Life Sciences Prague. All plant samples, samples of the SPD and the LPD, were dried at $35^{\circ} \mathrm{C}$ and then homogenized in a $1 \mathrm{~mm}$ sieve grinder.

\subsection{Determination of $p H$ Value and Content of Soluble Salts in Soil Samples}

From the chemical features, the $\mathrm{pH}$ value and the content of soluble salts in the aqueous extract of the sample and demineralized water were determined in a ratio of 1:10 (volume:weight). A $10 \mathrm{~g}$ sample of dried soil was weighed at $25^{\circ} \mathrm{C}$ into plastic PE bottles with lids and poured into $100 \mathrm{~mL}$ of distilled water. The samples were shaken for $5 \mathrm{~min}$ and then stood still for $5 \mathrm{~min}$. The measurement was performed with a calibrated $\mathrm{pH}$ meter and a calibrated conductometer marked HI 991,300 Hanna Instruments.

\subsection{Determination of Individual Nitrogen Forms in Soil Samples}

For the purpose of the analysis, $10 \mathrm{~g}$ of fresh homogenized soil (sieved through a mesh size of $5 \mathrm{~mm}$ ) was weighed into $250 \mathrm{~mL}$ polyethylene bottles and filled with $100 \mathrm{~mL}$ of a $0.01 \mathrm{~mol} / \mathrm{L} \mathrm{CaCl}_{2}$ solution. The solution was then shaken for two hours. The samples were then removed and filtered. The total contents of mineral nitrogen, ammonium and nitrate form were determined in fresh soil by the colorimetric method on the SKALAR SAN ${ }^{\text {PLUS }}$ SYSTEM analyzer (Breda, The Netherlands).

\subsection{Determination of Acceptable Nutrients from Soil Samples According to Mehlich 3}

The soil samples were dried at $35^{\circ} \mathrm{C}$ and then sieved through a sieve with a mesh diameter of $2 \mathrm{~mm}$. A $10 \mathrm{~g}$ sample soil was weighed into plastic PE bottles, which was extracted with $100 \mathrm{~mL}$ of Mehlich 3 reagent [56]. Shaking was performed for $10 \mathrm{~min}$, and then the obtained solution was filtered. Individual extracts were analyzed for phosphate content by the colorimetric method with ICP OES. The extracts were also measured for potassium, magnesium and calcium using an atomic absorption spectrometer (ASS), type Varian Vista Pro (Mulgrave, Australia).

\subsection{Determination of Nitrogen Content in Samples of Plant Material}

The Kjeldahl method was used to determine the total nitrogen content of the plant material. Total nitrogen includes both organic and ammoniacal nitrogen. For the determination, $0.50 \mathrm{~g}$ of a dry homogenized sample of plant material was weighed and mineralized. Mineralization took place in glass cuvettes. To the sample in the cuvette, $2 \mathrm{~g}$ of catalyst (mixture of $100 \mathrm{~g} \mathrm{~K}_{2} \mathrm{SO}_{4}, 1 \mathrm{~g} \mathrm{CuSO}_{4}, 0.1 \mathrm{~g} \mathrm{Se}$ ) and $10 \mathrm{~mL}$ of concentrated sulfuric acid $\left(\mathrm{H}_{2} \mathrm{SO}_{4}\right)$ were added. Decomposition was performed for $90 \mathrm{~min}$ at $420^{\circ} \mathrm{C}$. After mineralization, the samples were prepared for distillation by adding $20 \mathrm{~mL}$ of distilled water to the cuvette, which was placed in the Gerhardt Vapodest 30s (Königswinter, Germany). Then, distillation into $\mathrm{H}_{3} \mathrm{BO}_{3}$ took place, and the total nitrogen content in the sample was determined.

\subsection{Determination of Macronutrients, Micronutrients and Hazardous Substances Using an Absorption Spectrometer}

The decomposition of the samples was carried out in a microwave system in cuvettes, into which $0.5 \mathrm{~g}$ of dry plant material, SPD and LPD, ground to a fraction size of $1 \mathrm{~mm}$, was weighed. Then, $8 \mathrm{~mL}$ of $\mathrm{HNO}_{3}\left(65 \%\right.$ p.a.) and $2 \mathrm{~mL}$ of $\mathrm{H}_{2} \mathrm{O}_{2}\left(30 \% \mathrm{H}_{2} \mathrm{O}\right.$ p.a.) were added to the sample. The resulting mineralizate was evaporated after $20 \mathrm{~min}$. Internal reference material (IRM) analysis was performed on each series of samples. The contents 
of macroelements, microelements and hazardous elements were determined by ICP-OES (Varian Vista Pro, Mulgrave, Australia).

\subsection{Statistical Evaluation}

As part of the statistical evaluation, the average yields of fresh and dry biomass, nutrient content and nutrient intake of individual cannabis variants were statistically evaluated by the Statistica 12 program (Statsoft) by a test of homogeneity of variance and then by an analysis of variance $(p \leq 0.05)$. More detailed differences between individual averages were evaluated by Tukey's HSD test $(p \leq 0.05)$.

\section{Results and Discussion}

The SPD and the LPD used for fertilization were characterized by a $\mathrm{pH}$ value ranging from 8.3-8.6, which matches the approach of Makádi, Tomócsik and Orosz [16]. The LPD obtained on the pressure production separator contained, on average, $6.04 \%$ of dry matter, which was significantly more than stated by Kolár et al. [26]. This was probably due to the meshes in the sieve, which, due to their size, allowed the passage of small solid particles into the LPD. Tables 2 and 3 show the different contents of soluble salts. In the SPD, the content of dry matter was more than twice as much as in the LPD, which coincides with the approach of Makádi et al. [16].

Table 2. Specifications of applied SPD in dry mass.

\begin{tabular}{ccccccccc}
\hline $\begin{array}{c}\text { Dry Matter } \\
(\mathbf{\%})\end{array}$ & $\begin{array}{c}\mathbf{p H} \\
(\mathbf{H} \mathbf{O})\end{array}$ & $\begin{array}{c}\mathrm{EC} \\
(\mathbf{m S} / \mathbf{c m})\end{array}$ & $\begin{array}{c}\text { Total N } \\
(\mathbf{m g} / \mathbf{k g})\end{array}$ & $\begin{array}{c}\mathbf{P} \\
(\mathbf{m g} / \mathbf{k g})\end{array}$ & $\begin{array}{c}\mathbf{K} \\
(\mathbf{m g} / \mathbf{k g})\end{array}$ & $\begin{array}{c}\mathbf{C a} \\
(\mathbf{m g} / \mathbf{k g})\end{array}$ & $\begin{array}{c}\mathbf{M g} \\
(\mathbf{m g} / \mathbf{k g})\end{array}$ & $\begin{array}{c}\mathbf{S} \\
(\mathbf{m g} / \mathbf{k g})\end{array}$ \\
\hline $21.71 \pm 0.261$ & $8.6 \pm 0.141$ & $2.749 \pm 0.072$ & $24,900 \pm 452$ & $3127 \pm 129$ & $29,419 \pm 632$ & $40,358 \pm 772$ & $4364 \pm 518$ & $2793 \pm 516$ \\
\hline $\begin{array}{r}\mathbf{F e} \\
(\mathbf{m g} / \mathbf{k g})\end{array}$ & $\begin{array}{c}\mathbf{Z n} \\
(\mathbf{m g} / \mathbf{k g})\end{array}$ & $\begin{array}{c}\mathbf{C u} \\
(\mathbf{m g} / \mathbf{k g})\end{array}$ & $\begin{array}{c}\mathbf{B} \\
(\mathbf{m g} / \mathbf{k g})\end{array}$ & $\begin{array}{c}\mathbf{M n} \\
(\mathbf{m g} / \mathbf{k g})\end{array}$ & $\begin{array}{c}\mathbf{P b} \\
(\mathbf{m g} / \mathbf{k g})\end{array}$ & $\begin{array}{c}\mathbf{C d} \\
(\mathbf{m g} / \mathbf{k g})\end{array}$ & $\begin{array}{c}\mathbf{C r} \\
(\mathbf{m g} / \mathbf{k g})\end{array}$ & $\begin{array}{c}\mathbf{A s} \\
(\mathbf{m g} / \mathbf{k g})\end{array}$ \\
\hline $296 \pm 23.3$ & $90 \pm 9.33$ & $5.65 \pm 0.919$ & $70.1 \pm 19.5$ & $144 \pm 10.8$ & $0.065 \pm 0.001$ & $0.085 \pm 0.002$ & $1.425 \pm 0.13$ & $0.07 \pm 0.001$ \\
\hline
\end{tabular}

Table 3. Specifications of the LPD applied in dry mass.

\begin{tabular}{|c|c|c|c|c|c|c|c|c|}
\hline $\begin{array}{c}\text { Dry Matter } \\
(\%)\end{array}$ & $\begin{array}{c}\mathrm{pH} \\
\left(\mathrm{H}_{2} \mathrm{O}\right)\end{array}$ & $\begin{array}{c}\text { EC } \\
(\mathrm{mS} / \mathrm{cm})\end{array}$ & $\begin{array}{l}\text { Total N } \\
(\mathrm{mg} / \mathrm{kg})\end{array}$ & $\begin{array}{c}\mathbf{P} \\
(\mathrm{mg} / \mathrm{kg})\end{array}$ & $\begin{array}{c}\mathrm{K} \\
(\mathrm{mg} / \mathrm{kg})\end{array}$ & $\begin{array}{c}\mathrm{Ca} \\
(\mathrm{mg} / \mathrm{kg})\end{array}$ & $\begin{array}{c}\mathrm{Mg} \\
(\mathrm{mg} / \mathrm{kg})\end{array}$ & $\begin{array}{c}\mathrm{S} \\
(\mathrm{mg} / \mathrm{kg})\end{array}$ \\
\hline $6.04 \pm 0.127$ & $8.35 \pm 0.353$ & $>4000 \pm 0$ & $57,800 \pm 1265$ & $12,912 \pm 562$ & $42,988 \pm 1214$ & $39,996 \pm 2586$ & $4268 \pm 272$ & $3228 \pm 342$ \\
\hline $\begin{array}{c}\mathrm{Fe} \\
(\mathrm{mg} / \mathrm{kg})\end{array}$ & $\underset{(\mathrm{mg} / \mathrm{kg})}{\mathrm{Zn}}$ & $\begin{array}{c}\mathrm{Cu} \\
(\mathrm{mg} / \mathrm{kg})\end{array}$ & $\begin{array}{c}\text { B } \\
(\mathrm{mg} / \mathrm{kg})\end{array}$ & $\underset{(\mathrm{mg} / \mathrm{kg})}{\mathrm{Mn}}$ & $\begin{array}{c}\mathrm{Pb} \\
(\mathrm{mg} / \mathrm{kg})\end{array}$ & $\begin{array}{c}\mathrm{Cd} \\
(\mathrm{mg} / \mathrm{kg})\end{array}$ & $\begin{array}{c}\mathrm{Cr} \\
(\mathrm{mg} / \mathrm{kg})\end{array}$ & $\underset{(\mathrm{mg} / \mathrm{kg})}{\mathrm{As}}$ \\
\hline $267 \pm 96$ & $251 \pm 68$ & $6.1 \pm 0.52$ & $76.5 \pm 12.5$ & $189 \pm 15.7$ & $0.9 \pm 0.02$ & $0.09 \pm 0.001$ & $1.01 \pm 0.02$ & $3.79 \pm 0.12$ \\
\hline
\end{tabular}

Furthermore, the LPD was characterized by an approximately twice greater content of total N compared to the SPD, even when taking into account errors according to the standard deviation. The total contents of other macronutrients were similar for both applied raw materials. Of the macronutrients, the greatest content was found for calcium in the applied SPD. The contents of macroelements and microelements in the SPD and the LPD coincide with the approaches of Makádi et al. [16], Kolář et al. [26] and Dubský et al. [29]. Analyses of the SPD and LPD confirmed the findings of Makadi et al. [28], in which these raw materials possess features suitable for plant nutrition. Of the micronutrients, the greatest content was found for iron and zinc. The lowest content in both materials analyzed found was for copper. Both components, SPD and the LPD, were characterized by a low content of hazardous substances. Therefore, neither the SPD nor the LPD posed a risk of soil contamination and transport of these substances to the plant parts of cannabis.

Tables 4 and 5 show the individual nutritional variants of the experiment, recalculated for the application of $\mathrm{kg}$ of a nutrient per hectare. 
Table 4. Specifications of applied NPK in relation to the application of nutrients per hectare of soil.

\begin{tabular}{ccc}
\hline Total $\mathbf{N}$ & $\mathbf{P}$ & $\mathbf{K}$ \\
\hline$(\mathrm{kg} / \mathrm{ha})$ & $(\mathrm{kg} / \mathrm{ha})$ & $(\mathrm{kg} / \mathrm{ha})$ \\
\hline 150.0 & 20.0 & 150.0 \\
\hline
\end{tabular}

Table 5. Specifications of the applied SPD, SPD + LPD and LPD in relation to the application of nutrients per hectare of soil.

\begin{tabular}{cccc}
\hline & SPD & SPD + LPD & LPD \\
\hline Total N & & $\mathbf{( k g / h a )}$ & \\
P & 150.50 & 150.70 & 150.8 \\
K & 18.90 & 26.30 & 33.7 \\
$\mathrm{Ca}$ & 177.80 & 145.00 & 112.2 \\
$\mathrm{Mg}$ & 243.90 & 174.20 & 104.4 \\
$\mathrm{~S}$ & 26.40 & 18.80 & 11.1 \\
$\mathrm{Fe}$ & 16.90 & 12.70 & 8.4 \\
$\mathrm{~B}$ & 1.80 & 1.20 & 0.7 \\
$\mathrm{Mn}$ & 0.40 & 0.30 & 0.2 \\
\hline
\end{tabular}

Table 6 presents the analysis of soils before sowing cannabis seeds according to nutritional variants, two weeks after fertilizer application.

Table 6. Soils before sowing.

\begin{tabular}{|c|c|c|c|c|c|c|c|c|c|}
\hline Variant & $\begin{array}{c}\text { Nitrate N } \\
\text { (mg/kg) }\end{array}$ & $\underset{(\mathrm{mg} / \mathrm{kg})}{\operatorname{Ammonia} \mathrm{N}}$ & $\begin{array}{l}\text { Carbon } \\
\text { (mg/kg) }\end{array}$ & $\begin{array}{l}\text { Total N } \\
(\mathrm{mg} / \mathrm{kg})\end{array}$ & $\begin{array}{c}\mathrm{P} \\
(\mathrm{mg} / \mathrm{kg})\end{array}$ & $\begin{array}{c}\mathrm{K} \\
(\mathrm{mg} / \mathrm{kg})\end{array}$ & $\begin{array}{c}\mathrm{Ca} \\
(\mathrm{mg} / \mathrm{kg})\end{array}$ & $\underset{(\mathrm{mg} / \mathrm{kg})}{\mathrm{Mg}}$ & $\begin{array}{c}\mathrm{S} \\
(\mathrm{mg} / \mathrm{kg})\end{array}$ \\
\hline NPK & 21.25 & 29.96 & 287.79 & 57.50 & 534.56 & 502.78 & 8170.00 & 221.89 & 24.44 \\
\hline SPD & 17.18 & 25.62 & 291.63 & 50.35 & 542.89 & 545.56 & 8233.33 & 234.44 & 25.56 \\
\hline SPD + LPD & 9.31 & 17.83 & 303.57 & 39.62 & 548.89 & 543.33 & 8190.00 & 246.89 & 26.26 \\
\hline LPD & 8.97 & 15.35 & 294.41 & 33.24 & 530.50 & 523.63 & 8443.75 & 234.75 & 25.23 \\
\hline
\end{tabular}

The average dry mass yield of cannabis plants is shown in Figure 1. There were no significant differences between variants caused by the high non-uniformity of harvested plants in the field experiment. Similar results were reported by Tsachidou et al., who claim that applications of anaerobic digestion residues as a nitrogen source have shown the ability to maintain forage yields at a similar level as when using mineral NPK fertilizer. At the same time, the environmental risk associated with nitrogen leaching is reduced in this practice [23]. In both years, the average biomass yield was greatest in the variant fertilized by a divided dose of SPD and LPD (8.68 tons/ha), while the lowest dry mass yield was found in the variant where NPK was applied (7.45 tons/ha). The yield differences between the variants were statistically insignificant. The greatest yield in the variant with pre-sown-applied SPD and with fertilization with LPD was probably caused by the sufficient development of the root system in soil fertilized with a lower dose of SPD and regular fertilization with LPD during vegetation, which coincides with the findings of Alaru et al. [50] and Landi [48]. 


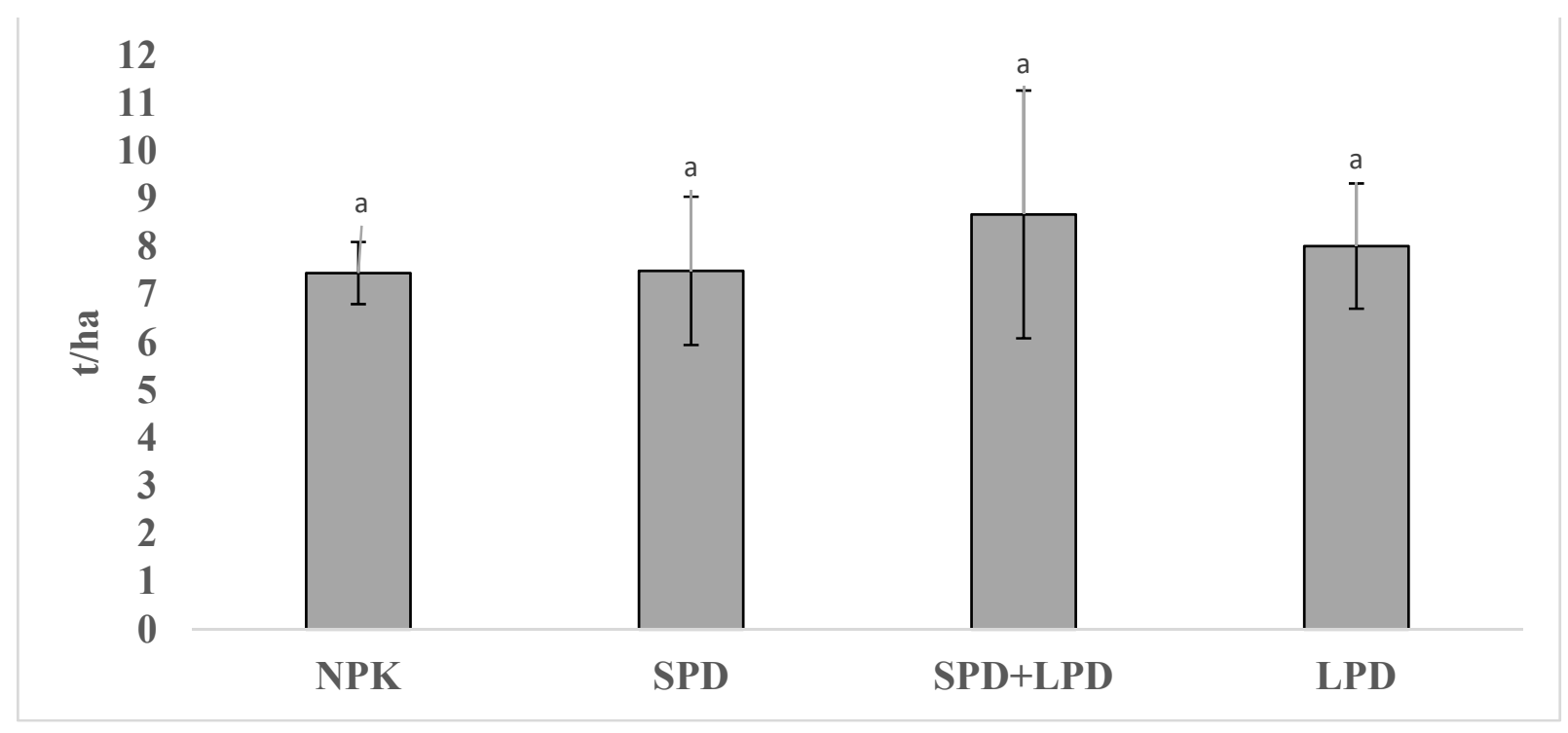

Figure 1. Average dry biomass yield of cannabis with individual variants.

The divided application of the LPD in the phase of intensive cannabis growth ensured a sufficient increase in biomass, which was reflected in the second greatest yield in the experiment. The results agree with the statements of Landi [48] and Barron et al. [47], who both state that the greatest nitrogen intake by cannabis plants is in the phase of their intensive growth. Nitrogen is also a key factor that influences the quantity and quality of cannabis production [57].

The contents of macronutrients, micronutrients and hazardous substances in dry matter in individual parts of cannabis plants are shown in Tables 7 and 8 . The differences between the individual variants were not statistically significant for any of the analyzed plant parts. Overall, the greatest $\mathrm{N}$ content was found in cannabis leaves and decreased in the order of stem and root.

In the SPD + LPD variant, the greatest content of N (3.5\%) was found in the leaves and stems $(2.15 \%)$ of cannabis. The value found is slightly lower than that indicated by Iványi and Izsáki [53]. In contrast, the lowest nitrogen concentration in the leaves was found after the application of a divided dose of the LPD $(3.2 \%)$ in the stems $(1.95 \%)$ and roots $(0.57 \%)$ of the NPK variant. The nitrogen concentration in the stems of all variants was lower than indicated by Hakala et al. [58], except for in the roots, in which it was relatively similar $(0.61 \%)$.

Similar to N, other macronutrients were found in higher amounts in the leaves and in significantly lower amounts in the stems and roots, where they did not differ statistically. The greatest content in the leaves was found for calcium in the variant fertilized with NPK, which could have been caused by the release of a significant amount of calcium after a single application of water-soluble fertilizers. Our assumptions are also confirmed by the fact that the lowest calcium content was measured in cannabis leaves in the variant fertilized SPD, where, on the contrary, the share of available nutrients was clearly the lowest. In the case of other evaluated macronutrients, their content in leaves or in other parts of the plant did not significantly statistically differ between individual variants. Phosphorus and potassium contents in cannabis leaves were, on average, lower than $0.5-0.6 \% \mathrm{P}$ and $2.7-3 \% \mathrm{~K}$, which Ivanyi [49] had stated regarding young leaves.

This was probably due to the fact that, in our case, the leaves of the whole plant were analyzed, including old and dried leaves, which both contain significantly fewer nutrients.

When evaluating the content of micronutrients, the trend of their accumulation in individual parts of plants was far from unambiguous, as in the case of macronutrients (Table 8). Again, most of the elements accumulated in the highest concentrations in the leaves; only iron was found in the greatest concentrations in the roots, thus confirming its 
limited mobility [59]. Despite its high accumulation in the roots, its content in the leaves was also the greatest of all monitored microelements. Lower contents were determined for boron and manganese and the lowest were found for zinc and copper. Overall, the contents of micronutrients in cannabis plants corresponded to the values reported by Ivanyi [49]. Differences in the contents of microelements in individual parts of plants were not statistically affected by the fertilizer used. The contents of molybdenum and risk elements were low in all plant parts, specifically below the detection limit of the analytical technique used.

Table 7. Macronutrient contents in individual parts of cannabis in dry biomass.

\begin{tabular}{|c|c|c|c|}
\hline \multirow{2}{*}{ Variant } & Root & Stem & Leaf \\
\hline & \multicolumn{3}{|c|}{ Calcium (\%) } \\
\hline NPK & $0.59^{\mathrm{a}}$ & $0.89^{a}$ & $3.40^{\mathrm{a}}$ \\
\hline SPD & $0.60^{\mathrm{a}}$ & $0.80^{\mathrm{a}}$ & $2.07^{\mathrm{a}}$ \\
\hline SPD + LPD & $0.61^{\mathrm{a}}$ & $0.47^{\mathrm{a}}$ & $2.81^{\mathrm{a}}$ \\
\hline LPD & $0.57^{\mathrm{a}}$ & $0.68^{a}$ & $2.85^{\mathrm{a}}$ \\
\hline Variant & \multicolumn{3}{|c|}{ Magnesium (\%) } \\
\hline NPK & $0.079^{a}$ & $0.100^{a}$ & $0.32^{\mathrm{a}}$ \\
\hline SPD & $0.076^{\mathrm{a}}$ & $0.089^{a}$ & $0.30^{\mathrm{a}}$ \\
\hline SPD + LPD & $0.130^{b}$ & $0.060^{\mathrm{a}}$ & $0.23^{\mathrm{a}}$ \\
\hline LPD & $0.083^{a}$ & $0.093^{\mathrm{a}}$ & $0.24^{\mathrm{a}}$ \\
\hline Variant & \multicolumn{3}{|c|}{ Sulfur (\%) } \\
\hline NPK & $0.047^{\mathrm{a}}$ & $0.036^{a}$ & $0.14^{\mathrm{a}}$ \\
\hline SPD & $0.034^{\mathrm{a}}$ & $0.034^{\mathrm{a}}$ & $0.12^{\mathrm{a}}$ \\
\hline SPD + LPD & $0.055^{\mathrm{a}}$ & $0.030^{\mathrm{a}}$ & $0.10^{\mathrm{a}}$ \\
\hline LPD & $0.049^{a}$ & $0.032^{\mathrm{a}}$ & $0.12^{\mathrm{a}}$ \\
\hline \multirow{2}{*}{ Variant } & Root & Stem & Leaf \\
\hline & \multicolumn{3}{|c|}{ Nitrogen $(\%)$} \\
\hline NPK & $0.57^{\mathrm{a}}$ & $1.95^{\mathrm{a}}$ & $3.36^{\mathrm{a}}$ \\
\hline SPD & $0.73^{\mathrm{a}}$ & $1.98^{\mathrm{a}}$ & $3.30^{\mathrm{a}}$ \\
\hline SPD + LPD & $0.73^{a}$ & $2.15^{\mathrm{a}}$ & $3.53^{\mathrm{a}}$ \\
\hline LPD & $0.75^{\mathrm{a}}$ & $2.01^{\mathrm{a}}$ & $3.22^{\mathrm{a}}$ \\
\hline Variant & \multicolumn{3}{|c|}{ Phosphorus (\%) } \\
\hline NPK & $0.11^{\mathrm{a}}$ & $0.11^{\mathrm{a}}$ & $0.24^{\mathrm{a}}$ \\
\hline SPD & $0.096^{\mathrm{a}}$ & $0.12^{\mathrm{a}}$ & $0.25^{\mathrm{a}}$ \\
\hline SPD + LPD & $0.14^{\mathrm{a}}$ & $0.089^{a}$ & $0.21^{\mathrm{a}}$ \\
\hline LPD & $0.11^{\mathrm{a}}$ & $0.11^{\mathrm{a}}$ & $0.21^{\mathrm{a}}$ \\
\hline Variant & \multicolumn{3}{|c|}{ Potassium (\%) } \\
\hline NPK & $1.31^{\mathrm{a}}$ & $1.27^{\mathrm{a}}$ & $1.98^{\mathrm{a}}$ \\
\hline SPD & $1.10^{\mathrm{a}}$ & $1.18^{\mathrm{a}}$ & $1.95^{\mathrm{a}}$ \\
\hline SPD + LPD & $1.20^{\mathrm{a}}$ & $1.37^{\mathrm{a}}$ & $1.75^{\mathrm{a}}$ \\
\hline LPD & $1.28^{\mathrm{a}}$ & $1.21^{\mathrm{a}}$ & $1.92^{\mathrm{a}}$ \\
\hline
\end{tabular}

Different superscript letters indicate statistical significance.

Figure 2 shows the average macronutrient total uptake of cannabis plants in $\mathrm{kg} / \mathrm{ha}$. Consumption by plants was calculated on the basis of the yield of individual parts of dry biomass on the plot and the content of individual nutrients in these parts of cannabis plants. The calculated samples confirmed that cannabis plants have a high uptake capacity and that nutrient samples exceeded their application rates in all cases. For this ability, cannabis is also commonly used in soil phytoremediation [60,61]. Overall, the greatest average consumption, at a level of about $300 \mathrm{~kg} / \mathrm{ha}$, was determined to be for nitrogen, only slightly lower for potassium, and at a level of $200 \mathrm{~kg} / \mathrm{ha}$ for calcium. LPD and SPD fertilization led to higher $\mathrm{N}$ and $\mathrm{K}$ uptake on all variants in comparison with the variant 
fertilized with NPK. The greatest nitrogen uptake was found in plants in the variant with a divided dose of SPD and LPD. The high nitrogen uptake was probably caused by a sufficient supply of accessible nitrogen during the growing season. This effect can only be expected with the direct application of digestates immediately incorporated into the soil to minimize losses of ammonia $\mathrm{N}$ present in high portions in both components of the digestate [19]. Nitrogen uptake in the mentioned variants exceeds the values presented by Ivanyi and Izsaki [52], who both reported an average sampling over a four-year trial of $213 \mathrm{~kg} \mathrm{~N} / \mathrm{ha}$. On the contrary, the plants in the variant with the application of NPK achieved the lowest nitrogen uptake. In addition, the results of Sogn et al. showed that digestates are a promising alternative to NPK mineral fertilizers, although the levels of K and $P$ in particular may fluctuate in these raw materials. When evaluating wheat yields using anaerobic digestion residues, comparable yields were achieved when using NPK fertilizer as a control [24].The greatest potassium uptake was again determined in the variant with the divided dose of SPD and LPD (345 kg/ha) and the lowest was in the variant with NPK (179 kg/ha). The observed values of potassium uptake by cannabis plants in the experiment are higher than indicated in Barron, Coutinho, English, Gergely, Lidouren and Haugaard-Nielsen [47]. The authors stated the range of potassium intake to be in the range of $75-300 \mathrm{~kg} / \mathrm{ha}$.

Table 8. Contents of micronutrients $(\mathrm{mg} / \mathrm{kg})$ in individual parts of cannabis in dry mass.

\begin{tabular}{|c|c|c|c|}
\hline \multirow{2}{*}{ Variant } & Root & Stem & Leaf \\
\hline & \multicolumn{3}{|c|}{ Iron (ppm) } \\
\hline NPK & $182^{a}$ & $28.84^{\mathrm{a}}$ & $94.61^{\mathrm{a}}$ \\
\hline SPD & $280^{a}$ & $50.72^{a}$ & $77.38^{a}$ \\
\hline SPD + LPD & $236^{a}$ & $33.90^{\mathrm{a}}$ & $67.52^{\mathrm{a}}$ \\
\hline LPD & $125^{\mathrm{a}}$ & $49.07^{\mathrm{a}}$ & $73.01^{a}$ \\
\hline Variant & \multicolumn{3}{|c|}{ Manganese (ppm) } \\
\hline NPK & $21.29^{a}$ & $26.53^{a}$ & $54.14^{a}$ \\
\hline SPD & $20.96^{a}$ & $23.11^{\mathrm{a}}$ & $36.27^{\mathrm{a}}$ \\
\hline SPD + LPD & $22.76^{a}$ & $14.31^{\mathrm{a}}$ & $26.20^{a}$ \\
\hline LPD & $17.51^{\mathrm{a}}$ & $25.30^{a}$ & $37.93^{a}$ \\
\hline Variant & \multicolumn{3}{|c|}{ Boron (ppm) } \\
\hline NPK & $11.39^{a}$ & $12.50^{\mathrm{a}}$ & $45.73^{a}$ \\
\hline SPD & $12.79^{\mathrm{a}}$ & $15.65^{\mathrm{a}}$ & $41.82^{\mathrm{a}}$ \\
\hline SPD + LPD & $24.50^{\mathrm{a}}$ & $8.36^{\mathrm{a}}$ & $35.77^{a}$ \\
\hline LPD & $14.54^{\mathrm{a}}$ & $12.27^{\mathrm{a}}$ & $35.04^{\mathrm{a}}$ \\
\hline \multirow{2}{*}{ Variant } & Root & Stem & Leaf \\
\hline & \multicolumn{3}{|c|}{ Zinc (ppm) } \\
\hline NPK & $7.37^{\mathrm{a}}$ & $6.49^{a}$ & $19.24^{a}$ \\
\hline SPD & $7.18^{\mathrm{a}}$ & $6.07^{\mathrm{a}}$ & $13.62^{\mathrm{a}}$ \\
\hline SPD + LPD & $11.45^{\mathrm{a}}$ & $5.03^{\mathrm{a}}$ & $8.91^{\mathrm{a}}$ \\
\hline LPD & $6.54^{\mathrm{a}}$ & $6.34^{\mathrm{a}}$ & $15.71^{a}$ \\
\hline Variant & \multicolumn{3}{|c|}{ Copper (ppm) } \\
\hline NPK & $2.68^{a}$ & $2.31^{\mathrm{a}}$ & $4.72^{\mathrm{a}}$ \\
\hline SPD & $2.67^{\mathrm{a}}$ & $2.68^{a}$ & $4.62^{\mathrm{a}}$ \\
\hline SPD + LPD & $3.25^{b}$ & $2.28^{a}$ & $3.80^{\mathrm{a}}$ \\
\hline LPD & $2.64^{\mathrm{a}}$ & $2.64^{\mathrm{a}}$ & $4.45^{\mathrm{a}}$ \\
\hline
\end{tabular}

Different superscript letters indicate statistical significance. 


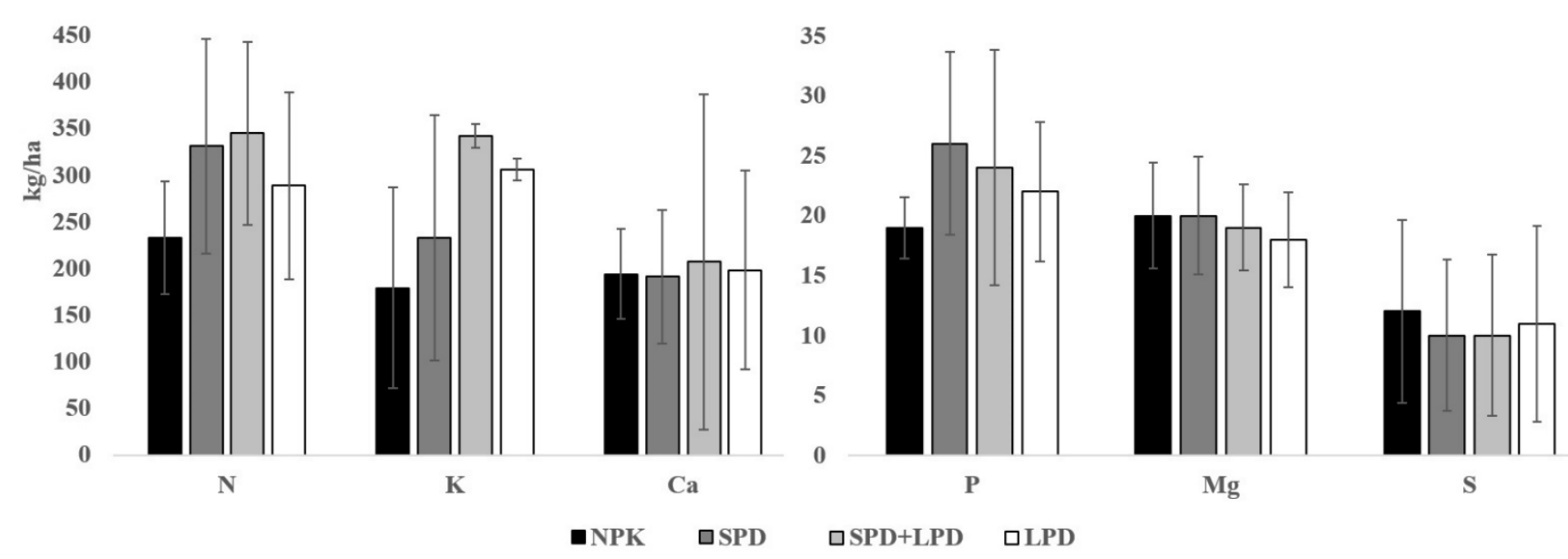

Figure 2. The average total uptake of cannabis macronutrients of individual experimental variants.

Calcium uptake by cannabis was high, not significantly affected by the fertilizer used and averaged at $191-207 \mathrm{~kg} / \mathrm{ha}$. These values correspond to the calcium samples given by Landi [48], at $150-227 \mathrm{~kg} \mathrm{Ca} / \mathrm{ha}$.

The average phosphorus uptake ranged from $19-26 \mathrm{~kg} / \mathrm{ha}$ and was higher for the variants fertilized with SPD and LPD than for the variant fertilized with NPK. These values match those of Landi [48], who reported P withdrawals by cannabis plants from 12 to $35 \mathrm{~kg} / \mathrm{ha}$. In addition, they are in line with the values stated by Ivanyi and Izsaki [52].

The average intakes of magnesium and sulfur were similar in all variants. The consumption of magnesium ranged from $18-20 \mathrm{~kg} / \mathrm{ha}$ and that of sulfur ranged from $10-12 \mathrm{~kg} / \mathrm{ha}$.

Micronutrient uptake by plants was significantly reduced (Figure 3). The greatest consumption was found for iron; the consumption was lower for manganese and boron and lowest for zinc and copper. In the case of iron and boron, fertilization by SPD and LPD had a favorable effect. Especially in the variant with a divided dose of SPD and the LPD, cannabis plants took up most of these microelements. The lowest consumption by plants was for manganese and boron in the variant fertilized with LPD and NPK. For other nutrients, no significant differences were found between the individual variants. A higher uptake of iron and boron by plants on variants with SPD and LPD was probably due to their higher content in these materials and easier accessibility (Tables 2 and 3).

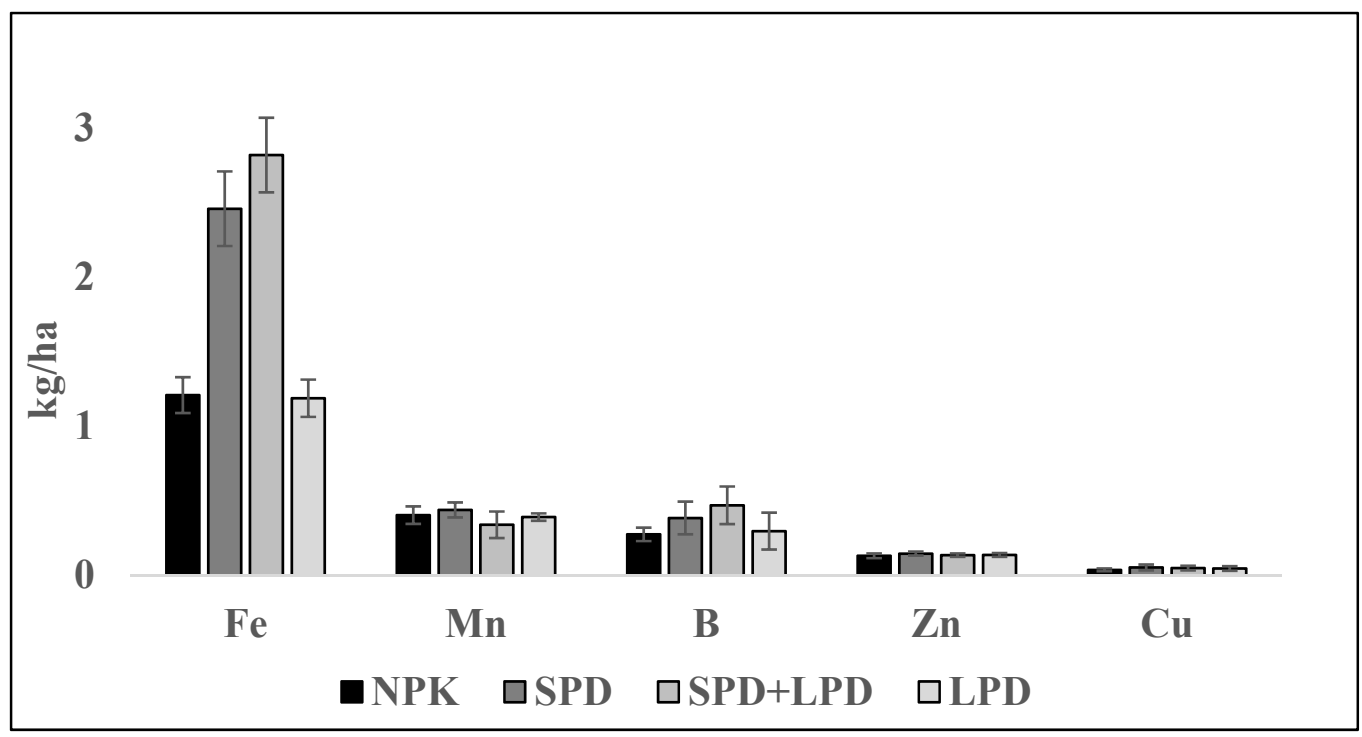

Figure 3. The average intakes of cannabis micronutrients of individual experimental variants (kg/ha). 
After each harvest, the basic agrochemical features were determined (Table 9). The obtained values confirmed that the experiment was based on fertile soil; therefore, the application of NPK, SPD and LPD did not have a statistically significant effect on the evaluated parameters. The $\mathrm{pH}$ value determined in the aqueous extract was similar for all variants and corresponded to a $\mathrm{pH}$ of 8.7. The content of dissolved salts in the soil was the same in all variants. Slight differences were found in the content of individual forms of mineral nitrogen. The nitrogen supplied by the LPD oxidized more rapidly, and the ammonium $\mathrm{N}$ content was the lowest for these variants. The improvement of the soil structure led to the greatest overall consumption of N on the SPD + LPD variant, which was reflected in the lowest content of nitrate $\mathrm{N}$ after the cannabis harvest on this variant.

Table 9. Dry matter content, $\mathrm{pH}$ value, soluble salt value and mineral nitrogen content in soil samples after plant harvest.

\begin{tabular}{cccccc}
\hline \multirow{2}{*}{ Variant } & Dry Matter (\%) & pH (H) & & \multicolumn{2}{c}{$\mathbf{N}(\mathbf{m g} / \mathbf{k g})$} \\
\cline { 4 - 6 } & & & $\mathbf{E C}(\mathbf{m S} / \mathbf{c m})$ & $\mathbf{N O}_{3}{ }^{-}$ & $\mathbf{N H}_{\mathbf{4}}{ }^{+}$ \\
\hline NPK & $90.8 \pm 0.07$ & $8.71 \pm 0.00$ & $0.114 \pm 0.008$ & $21.55 \pm 0.49$ & $18.35 \pm 6.33$ \\
SPD & $90.3 \pm 0.14$ & $8.74 \pm 0.04$ & $0.105 \pm 0.001$ & $21.12 \pm 5.53$ & $21.13 \pm 6.32$ \\
SPD + LPD & $89.7 \pm 0.07$ & $8.76 \pm 0.08$ & $0.110 \pm 0.013$ & $18.23 \pm 2.60$ & $15.54 \pm 3.34$ \\
LPD & $90.3 \pm 0.02$ & $8.73 \pm 0.02$ & $0.108 \pm 0.003$ & $23.09 \pm 2.06$ & $11.84 \pm 5.04$ \\
\hline
\end{tabular}

The contents of accessible nutrients and risk elements in the soil after the cannabis harvest confirmed that the application of LPD and SPD did not significantly affect their accumulation in the topsoil layer (Table 10). The high $\mathrm{pH}$ value was confirmed by the high content of accessible calcium, which did not differ between the individual variants of the experiment. The contents of other cations were also high. The K content was not affected by the applied fertilizer, and the $\mathrm{Mg}$ content was slightly increased on the variants fertilized with the LPD and SPD, which could be caused by its supply in organic fertilizers. This trend was reflected on a smaller scale in the case of the evaluation of the available sulfur content in the soil.

Table 10. Macronutrient content in soil samples after harvest of plants in dry matter.

\begin{tabular}{cccccc}
\hline Variant & $\mathbf{P}(\mathbf{m g} / \mathbf{k g})$ & $\mathbf{K}(\mathbf{m g} / \mathbf{k g})$ & $\mathbf{C a}(\mathbf{m g} / \mathbf{k g})$ & $\mathbf{M g} \mathbf{( m g} / \mathbf{k g})$ & $\mathbf{S}(\mathbf{m g} / \mathbf{k g})$ \\
\hline NPK & $614 \pm 113$ & $460 \pm 59$ & $7328 \pm 1190$ & $240 \pm 27.6$ & $29.0 \pm 7.1$ \\
SPD & $628 \pm 122$ & $468 \pm 108$ & $7637 \pm 843$ & $252 \pm 26.2$ & $30.5 \pm 7.8$ \\
SPD + LPD & $629 \pm 114$ & $479 \pm 90$ & $7367 \pm 1163$ & $253 \pm 10.6$ & $32.5 \pm 9.2$ \\
LPD & $613 \pm 117$ & $476 \pm 66$ & $7374 \pm 1512$ & $259 \pm 35.4$ & $34.5 \pm 13.4$ \\
\hline
\end{tabular}

Similar to the contents of the macroelements, the accessible content of microelements depended mainly on their amount in the soil and was only slightly affected by the applied SPD and LPD (Table 11). Only in the case of Cu can we assume that its high affinity for organic matter meant a slight decrease in its accessible forms in the soil. In the case of the micronutrients, their content depended on the habitat when assessing the accessible proportion of risk elements, and the applied fertilization did not lead to any significant changes in their content.

Table 11. Microelements content in soil samples after harvest of plants in dry matter.

\begin{tabular}{ccccccc}
\hline Sample & Fe (mg/kg) & $\begin{array}{c}\mathbf{Z n} \\
(\mathbf{m g} / \mathbf{k g})\end{array}$ & $\begin{array}{c}\mathbf{C u} \\
(\mathbf{m g} / \mathbf{k g})\end{array}$ & B (mg/kg) & $\begin{array}{c}\mathbf{M n} \\
(\mathbf{m g} / \mathbf{k g})\end{array}$ & $\begin{array}{c}\text { Mo } \\
(\mathbf{m g} / \mathbf{k g})\end{array}$ \\
\hline NPK & $62.6 \pm 19.1$ & $16.4 \pm 3.1$ & $9.87 \pm 1.59$ & $21.9 \pm 5.45$ & $291 \pm 78$ & $<0.005$ \\
SPD & $63.9 \pm 16.1$ & $16.9 \pm 3.2$ & $8.68 \pm 0.40$ & $20.6 \pm 3.33$ & $302 \pm 83$ & $<0.005$ \\
SPD + LPD & $64.5 \pm 15.1$ & $17.2 \pm 2.4$ & $8.82 \pm 0.31$ & $21.5 \pm 4.60$ & $299 \pm 74$ & $<0.005$ \\
LPD & $64.0 \pm 21.9$ & $17.0 \pm 3.6$ & $8.59 \pm 0.27$ & $21.4 \pm 4.81$ & $290 \pm 77$ & $<0.005$ \\
\hline
\end{tabular}


In conclusion, the data obtained from this experiment suggest that the by-products from anaerobic digestion can be used as an alternative to mineral NPK fertilizers. Comparable yield parameters were achieved by cannabis plants and were supported by a greater degree of nutrient accumulation in individual plant tissues. However, these materials are variable both in the composition of specific nutrients and in their accessibility to plants. This variability is due to differences of the input raw materials into the anaerobic digestion process, and this factor must be taken into account.

Author Contributions: Conceptualization, J.V., L.K. and P.T.; methodology, J.V., L.K. and P.T.; software, J.V., M.M.; validation J.V. and P.T.; formal analysis, J.V. and L.K.; investigation, J.V., L.K., M.M. and P.T.; resources, P.T.; data curation, J.V., M.M. and P.T.; writing—original draft preparation, J.V.; writing—review and editing, J.V.; visualization, J.V.; supervision, P.T.; project administration, P.T.; funding acquisition, P.T. All authors have read and agreed to the published version of the manuscript.

Funding: This research was funded by European Regional Development Fund project NUTRISK, grant number [CZ.02.1.01/0.0/0.0/16_019/0000845]. The financial support is greatly appreciated.

Institutional Review Board Statement: Not applicable.

Informed Consent Statement: Not applicable.

Data Availability Statement: Not applicable.

Conflicts of Interest: The authors declare no conflict of interest.

\section{References}

1. Tafdrup, S. Centralized biogas plants combine agricultural and environmental benefits with energy production. Water Sci. Technol. 1994, 30, 133. [CrossRef]

2. Zhang, $\mathrm{C}$; $\mathrm{Xu}, \mathrm{Y}$. Economic analysis of large-scale farm biogas power generation system considering environmental benefits based on LCA: A case study in China. J. Clean. Prod. 2020, 258, 120985. [CrossRef]

3. Börjesson, P.; Berglund, M. Environmental systems analysis of biogas systems-Part II: The environmental impact of replacing various reference systems. Biomass Bioenergy 2007, 31, 326-344. [CrossRef]

4. Raboni, M.; Urbini, G. Production and use of biogas in Europe: A survey of current status and perspectives. Rev. Ambiente Agua 2014, 9, 191-202.

5. Lošák, T.; Zatloukalová, A.; Szostková, M.; Hlušek, J.; Fryč, J.; Vítěz, T. Comparison of the effectiveness of digestate and mineral fertilisers on yields and quality of kohlrabi (Brassica oleracea, L.). Acta Univ. Agric. Silvic. Mendel. Brun. 2014, 59, 117-122. [CrossRef]

6. Rasi, S.; Veijanen, A.; Rintala, J. Trace compounds of biogas from different biogas production plants. Energy 2007, 32, 1375-1380. [CrossRef]

7. Weiland, P. Biogas production: Current state and perspectives. Appl. Microbiol. Biotechnol. 2010, 85, 849-860. [CrossRef] [PubMed]

8. Sahlström, L. A review of survival of pathogenic bacteria in organic waste used in biogas plants. Bioresour. Technol. 2003, 87, 161-166. [CrossRef]

9. Sassi, H.P.; Ikner, L.A.; Abd-Elmaksoud, S.; Gerba, C.P.; Pepper, I.L. Comparative survival of viruses during thermophilic and mesophilic anaerobic digestion. Sci. Total Environ. 2018, 615, 15-19. [CrossRef]

10. Johansen, A.; Nielsen, H.B.; Hansen, C.M.; Andreasen, C.; Carlsgart, J.; Hauggard-Nielsen, H.; Roepstorff, A. Survival of weed seeds and animal parasites as affected by anaerobic digestion at meso-and thermophilic conditions. Waste Manag. 2013, 33, 807-812. [CrossRef] [PubMed]

11. Zhou, L.; Hülsemann, B.; Merkle, W.; Guo, J.; Dong, R.; Piepho, H.-P.; Gerhards, R.; Müller, J.; Oechsner, H. Influence of Anaerobic Digestion Processes on the Germination of Weed Seeds. Gesunde Pflanz. 2020, 72, 181-194. [CrossRef]

12. Ditl, P.; Nápravník, J.; Šulc, R. Chemical pre-treatment of fugate from biogas stations. Biomass Bioenergy 2017, 96, 180-182. [CrossRef]

13. Kreuger, E.; Prade, T.; Escobar, F.; Svensson, S.-E.; Englund, J.-E.; Björnsson, L. Anaerobic digestion of industrial hemp-Effect of harvest time on methane energy yield per hectare. Biomass Bioenergy 2011, 35, 893-900. [CrossRef]

14. Prade, T.; Svensson, S.-E.; Andersson, A.; Mattsson, J.E. Biomass and energy yield of industrial hemp grown for biogas and solid fuel. Biomass Bioenergy 2011, 35, 3040-3049. [CrossRef]

15. Struik, P.; Amaducci, S.; Bullard, M.; Stutterheim, N.; Venturi, G.; Cromack, H. Agronomy of fibre hemp (Cannabis sativa L.) in Europe. Ind. Crop. Prod. 2000, 11, 107-118. [CrossRef]

16. Makádi, M.; Tomócsik, A.; Orosz, V. Digestate: A new nutrient source-review. Biogas 2012, 14, 295-312.

17. Lukehurst, C.T.; Frost, P.; Al Seadi, T. Utilisation of digestate from biogas plants as biofertiliser. IEA Bioenergy 2010, 2010, 1-36.

18. Kratzeisen, M.; Starcevic, N.; Martinov, M.; Maurer, C.; Müller, J. Applicability of biogas digestate as solid fuel. Fuel 2010, 89, 2544-2548. [CrossRef] 
19. Möller, K.; Müller, T. Effects of anaerobic digestion on digestate nutrient availability and crop growth: A review. Eng. Life Sci. 2012, 12, 242-257. [CrossRef]

20. Lijó, L.; González-García, S.; Bacenetti, J.; Negri, M.; Fiala, M.; Feijoo, G.; Moreira, M.T. Environmental assessment of farm-scaled anaerobic co-digestion for bioenergy production. Waste Manag. 2015, 41, 50-59. [CrossRef]

21. Teglia, C.; Tremier, A.; Martel, J.-L. Characterization of solid digestates: Part 1, review of existing indicators to assess solid digestates agricultural use. Waste Biomass Valorization 2011, 2, 43-58. [CrossRef]

22. Koszel, M.; Lorencowicz, E. Agricultural use of biogas digestate as a replacement fertilizers. Agric. Agric. Sci. Procedia 2015, 7, 119-124. [CrossRef]

23. Tsachidou, B.; Scheuren, M.; Gennen, J.; Debbaut, V.; Toussaint, B.; Hissler, C.; George, I.; Delfosse, P. Biogas residues in substitution for chemical fertilizers: A comparative study on a grassland in the Walloon Region. Sci. Total Environ. 2019, 666, 212-225. [CrossRef] [PubMed]

24. Sogn, T.A.; Dragicevic, I.; Linjordet, R.; Krogstad, T.; Eijsink, V.G.; Eich-Greatorex, S. Recycling of biogas digestates in plant production: NPK fertilizer value and risk of leaching. Int. J. Recycl. Org. Waste Agric. 2018, 7, 49-58. [CrossRef]

25. Abubaker, J.; Risberg, K.; Pell, M. Biogas residues as fertilisers-Effects on wheat growth and soil microbial activities. Appl. Energy 2012, 99, 126-134. [CrossRef]

26. Kolář, L.; Kužel, S.; Peterka, J.; Borová-Batt, J. Agrochemical value of the liquid phase of wastes from fermentem during biogas production. Plant Soil Environ. 2012, 56, 23-27. [CrossRef]

27. Möller, K.; Schulz, R.; Müller, T. Substrate inputs, nutrient flows and nitrogen loss of two centralized biogas plants in southern Germany. Nutr. Cycl. Agroecosyst. 2010, 87, 307-325. [CrossRef]

28. Makadi, M.; Tomocsik, A.; Eichler-Loebermann, B.; Schiemenz, K. nutrient cycling by using residues of bioenergy productioneffects of biogas-digestate on plant and soil parameters. Cereal Res. Commun. 2008, 36, 1807-1810.

29. Dubský, M.; Chaloupková, Š.; Kaplan, L.; Vondráčková, S.; Tlustoš, P. Use of solid phase of digestate for production of growing horticultural substrates. Hortic. Sci. 2019, 46, 34-42. [CrossRef]

30. What is the Digestate? Available online: https://air.unimi.it/retrieve/handle/2434/50234/110733/WhatIsTheDigestate.pdf (accessed on 10 October 2021).

31. Coelho, J.J.; Prieto, M.L.; Dowling, S.; Hennessy, A.; Casey, I.; Woodcock, T.; Kennedy, N. Physical-chemical traits, phytotoxicity and pathogen detection in liquid anaerobic digestates. Waste Manag. 2018, 78, 8-15. [CrossRef]

32. Holm-Nielsen, J.B.; Al Seadi, T.; Oleskowicz-Popiel, P. The future of anaerobic digestion and biogas utilization. Bioresour Technol. 2009, 100, 5478-5484. [CrossRef] [PubMed]

33. Godwin, H. The ancient cultivation of hemp. Antiquity 1967, 41, 42-49. [CrossRef]

34. Lu, X.; Clarke, R.C. The cultivation and use of hemp (Cannabis sativa L.) in ancient China. J. Int. Hemp Assoc. 1995, 2, 26-30.

35. Bradshaw, R.; Coxon, P.; Greig, J.; Hall, A. New fossil evidence for the past cultivation and processing of hemp (Cannabis sativa L.) in Eastern England. New Phytol. 1981, 89, 503-510. [CrossRef]

36. Decorte, T. Fibre hemp and marihuana: Assessing the differences between distinct varieties. Work. Pap. Ser. Polic. 2011, 38, 1-16.

37. Council Regulation (EC) No 1782/2003 of 29 September 2003 Establishing Common Rules for Direct Support Schemes under the Common Agricultural Policy and Establishing Certain Support Schemes for Farmers and Amending Regulations (EEC) No 2019/93, (EC) No 1452/2001, (EC) No 1453/2001, (EC) No 1454/2001, (EC) 1868/94, (EC) No 1251/1999, (EC) No 1254/1999, (EC) No 1673/2000, (EEC) No 2358/71 and (EC) No 2529/2001. Available online: https:/ / eur-lex.europa.eu/LexUriServ/LexUriServ. do?uri=CONSLEG:2003R1782:20090101:EN:PDF (accessed on 12 November 2021).

38. Commission Regulation, No.796/2004 of 21 April 2004. Laying Down Rules for the Implementation of Cross Compliance, Modulation and Integrated Administration and Control Provided for in Council Regulation (EC). Available online: https://eur-lex.europa.eu/ LexUriServ / LexUriServ.do?uri=OJ:L:2004:141:0018:0058:EN:PDF (accessed on 7 June 2020).

39. Prade, T. Industrial Hemp (Cannabis sativa L.)-A High-Yielding Energy Crop. Ph.D. Thesis, Swedish University of Agricultural Sciences, Alnarp, Sweden, 2011.

40. Burczyk, H.; Grabowska, L.; Kołodziej, J.; Strybe, M. Industrial hemp as a raw material for energy production. J. Ind. Hemp 2008, 13, 37-48. [CrossRef]

41. Finnan, J.; Styles, D. Hemp: A more sustainable annual energy crop for climate and energy policy. Energy Policy 2013, 58, 152-162. [CrossRef]

42. Van der Werf, H.M.G.; Wijlhuizen, M.; de Schutter, J.A.A. Plant density and self-thinning affect yield and quality of fibre hemp (Cannabis sativa L.). Field Crop. Res. 1995, 40, 153-164. [CrossRef]

43. Amaducci, S.; Amaducci, M.T.; Benati, R.; Venturi, G. Crop yield and quality parameters of four annual fibre crops (hemp, kenaf, maize and sorghum) in the North of Italy. Ind. Crop. Prod. 2000, 11, 179-186. [CrossRef]

44. Hemp as an Agricultural Commodity. Available online: https://sgp.fas.org/crs/misc/RL32725.pdf (accessed on 15 April 2019).

45. Vera, C.; Malhi, S.; Phelps, S.; May, W.; Johnson, E. N, P, and S fertilization effects on industrial hemp in Saskatchewan. Can. J. Plant Sci. 2010, 90, 179-184. [CrossRef]

46. Finnan, J.; Burke, B. Potassium fertilization of hemp (Cannabis sativa). Ind. Crop. Prod. 2013, 41, 419-422. [CrossRef]

47. Barron, A.; Coutinho, J.; English, A.; Gergely, S.; Lidouren, E.; Haugaard-Nielsen, H. Integrating hemp in organic farming systems-A Focus on the United Kingdom, France and Denmark. 2003. Available online: https://citeseerx.ist.psu.edu/viewdoc/ download?doi=10.1.1.198.8495\&rep=rep1\&type=pdf (accessed on 10 November 2021). 
48. Landi, S. Mineral nutrition of Cannabis sativa L. J. Plant Nutr. 1997, 20, 311-326. [CrossRef]

49. Ivanyi, I. Relationship between leaf nutrient concentration and the yield of fibre hemp (Cannabis sativa L.). Res. J. Agric. Sci. 2011, 43, 70-76. [CrossRef]

50. Alaru, M.; Kukk, L.; Astover, A.; Lauk, R.; Shanskiy, M.; Loit, E. An agro-economic analysis of briquette production from fibre hemp and energy sunflower. Ind. Crop. Prod. 2013, 51, 186-193. [CrossRef]

51. Malceva, M.; Vikmane, M.; Stramkale, V. Changes of photosynthesis-related parameters and productivity of Cannabis sativa under different nitrogen supply. Environ. Exp. Biol. 2011, 9, 61-69.

52. Ivanyi, I.; Izsaki, Z. Effect of nutrient supplies on the nutrient uptake of fibre hemp (Cannabis sativa L.) during the vegetation period. Novenytermeles 1996, 45, 181-193.

53. Iványi, I.; Izsáki, Z. Effect of nitrogen, phosphorus, and potassium fertilization on nutrional status of fiber hemp. Commun. Soil Sci. Plant Anal. 2009, 40, 974-986. [CrossRef]

54. Word Reference Base for Soil Resources-WRB. International Soil Classification System for Naming Soils and Creating Legends for Soil Maps; FAO: Geneva, Switzerland, 2014.

55. Sausserde, R.; Adamovičs, A. Impact of nitrogen fertilizer rates on industrial hemp growth and development. In Proceedings of the 19th International Scientific Conference on Research for Rural Development, Jeglava, Latvia, 17-19 September 2013; pp. 50-55.

56. Mehlich, A. Mehlich 3 soil test extractant: A modification of Mehlich 2 extractant. Commun. Soil Sci. Plant Anal. 1984, 15, 1409-1416. [CrossRef]

57. Papastylianou, P.; Kakabouki, I.; Travlos, I. Effect of nitrogen fertilization on growth and yield of industrial hemp (Cannabis sativa L.). Not. Bot. Horti Agrobot. Cluj-Napoca 2018, 46, 197-201. [CrossRef]

58. Hakala, K.; Keskitalo, M.; Eriksson, C.; Pitkänen, T. Nutrient uptake and biomass accumulation for eleven different field crops. Agric. Food Sci. 2009, 18, 366-387. [CrossRef]

59. Mengel, K. Iron availability in plant tissues-iron chlorosis on calcareous soils. Plant Soil 1994, 165, 275-283. [CrossRef]

60. Kumar, S.; Singh, R.; Kumar, V.; Rani, A.; Jain, R. Cannabis sativa: A plant suitable for phytoremediation and bioenergy production. In Phytoremediation Potential of Bioenergy Plants; Springer: Berlin/Heidelberg, Germany, 2017; pp. $269-285$.

61. Linger, P.; Müssig, J.; Fischer, H.; Kobert, J. Industrial hemp (Cannabis sativa L.) growing on heavy metal contaminated soil: Fibre quality and phytoremediation potential. Ind. Crop. Prod. 2002, 16, 33-42. [CrossRef] 